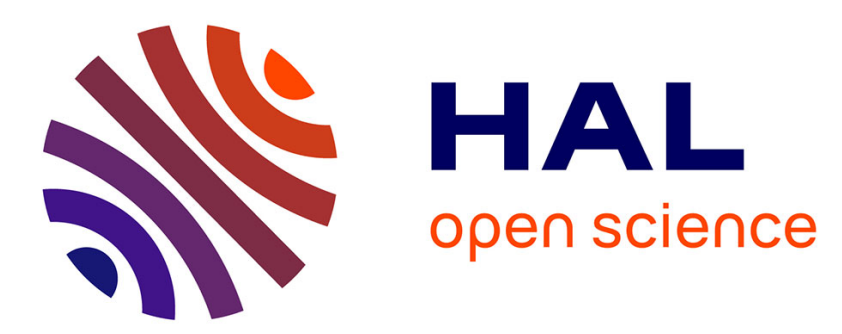

\title{
A reassessment of the Bovidae (Mammalia) from the Nawata Formation of Lothagam, Kenya, and the late Miocene diversification of the family in Africa
}

Denis Geraads

\section{- To cite this version:}

Denis Geraads. A reassessment of the Bovidae (Mammalia) from the Nawata Formation of Lothagam, Kenya, and the late Miocene diversification of the family in Africa. Journal of Systematic Palaeontology, 2017, pp.1 - 14. 10.1080/14772019.2017.1403493 . hal-01684030

\section{HAL Id: hal-01684030 \\ https: / hal.sorbonne-universite.fr/hal-01684030}

Submitted on 15 Jan 2018

HAL is a multi-disciplinary open access archive for the deposit and dissemination of scientific research documents, whether they are published or not. The documents may come from teaching and research institutions in France or abroad, or from public or private research centers.
L'archive ouverte pluridisciplinaire HAL, est destinée au dépôt et à la diffusion de documents scientifiques de niveau recherche, publiés ou non, émanant des établissements d'enseignement et de recherche français ou étrangers, des laboratoires publics ou privés. 
5

6

7

\title{
A reassessment of the Bovidae (Mammalia) from the Nawata Formation of
} Lothagam, Kenya, and the late Miocene diversification of the family in

\section{Africa}

\author{
Denis Geraads a, b
}

Mis en forme : Français (France)

Sorbonne Universités - CR2P-MNHN, CNRS, UPMC-Paris 6 - CP 38, Muséum National d'Histoire Naturelle, 8 rue Buffon, F-75231 Paris Cedex 05, France; denis.geraads@mnhn.fr ${ }^{\mathrm{b}}$ Max Planck Institute for Evolutionary Anthropology, Department of Human Evolution, Deutscher Platz 6 - D-04103 Leipzig - Germany

Abstract. The late Miocene Bovidae from the Nawata Formation of Lothagam were all assigned to modern tribes by Harris (2003), with the majority of specimens being referred to a species of Aepyceros, a genus that includes the modern impala. However, an alternative interpretation of the collection lessens the modern character of the faunal composition. Many of the identifications are revised; there might be a single species of Boselaphini, there is no evidence of Hippotragini, and Aepyceros is less common than previously thought. Two new genera, Afrotragus and Turkanatragus, are erected; together with an unnamed species and 'Kobus' laticornis Harris, 2003, they cannot easily be allocated to any existing tribe. These two new genera share long, slender, spiralled horn-cores, and it is conceivable that they belong to the same group, which might also include the 'Prostrepsiceros' from Sahabi, Libya, but does not seem closely related to Eurasian Prostrepsiceros. Along with sparser evidence from elsewhere in Africa, this strongly suggests that by the Late Miocene, African Bovidae underwent a wider radiation than reflected in the tribes that survived into the Pliocene, showing that the crown groups very incompletely document the relatively recent past diversity of the family.

Keywords. Africa, Kenya, Mammalia, Bovidae, Late Miocene, diversity

\section{Introduction}

The Lothagam area in North-Western Kenya, which yielded over 100 mammalian taxa, is one of the richest late Neogene sites in Africa (Leakey \& Harris 2003). It spans a long 
time period, from the Late Miocene to the Late Pliocene, and is thus critical for deciphering the evolution of many African mammalian groups that diversified in the Late Neogene. The most fossiliferous part of the sequence is the Nawata Formation, with two members, the Lower Nawata dated to 7.44 to $6.54 \mathrm{Ma}$, and the Upper Nawata dated to less than 6.54 Ma. The Nawata Formation is overlain by the Apak Member of the Nachukui Formation, which includes a tephra unit dated at 4.22 Ma and is overlain by the Lothagam Basalt. The Kaiyumung Member overlays the lacustrine sediments of the Muonogori Member but its age is poorly constrained (Feibel 2003: McDougall \& Feibel 2003). The site was first surveyed by B. Patterson from 1967 onwards, and from 1989 onwards by M. Leakey and colleagues; the fossils discussed here were collected by both parties. A detailed history of the research at Lothagam can be found in Leakey (2003).

In the monograph devoted to the site, Harris (2003) described 16 species of Bovidae in the Nawata Formation, which he all assigned to tribes still existing today, although one of them, the Boselaphini, is now restricted to Asia. These species were (with their original spelling and tribal attribution): Tragelaphus kyaloae (Tragelaphini), an unidentified Bovini, Tragoportax aff. cyrenaicus, Tragoportax sp. A, Tragoportax sp. B (Boselaphini), Kobus presigmoidalis, K. laticornis, Menelikia leakeyi (Reduncini), Praedamalis ? sp., Hippotragus sp. (Hippotragini), Damalacra sp. A, Damalacra sp. B (Alcelaphini), Aepyceros premelampus (Aepycerotini), Gazella sp., Raphiceras sp., Madoqua sp. (Antilopini). To this list he added Tragelaphus cf. scriptus from the Kaiyumung Member, Simatherium aff. kohllarseni (Bovini) from the Kaiyumung and Apak Members, and Tragelaphus nakuae, represented by a single specimen of unknown stratigraphic provenance. Some comments on the Bovidae from these members are provided in Supplemental material A, but the present work focuses on those from the Nawata Formation.

According to Harris (2003:531-532), they 'seemingly represent some of the first representatives of the tribes characteristic of Africa today'. Indeed, in spite of some turnover at the generic level, with the extinction of the genera Tragoportax, Simatherium, Menelikia and Damalacra since those times, this assemblage would suggest a relative stability of the tribal composition, after the early diversification of the African endemic tribes (Bibi et al. 2009).

The present revision partly confirms Harris' conclusions, but also reassesses the identifications and affinities of many specimens and their relationships to modern taxa, leading to a reevaluation of the supposed modern character of the bovid fauna, and 
emphasizing instead the occurrence in the Nawata Formation of several taxa that cannot be assigned to any of the crown groups.

\section{Materials and methods}

The bovid collection from Lothagam was examined in the National Museums of Kenya (KNM) during several visits from 2005 to 2016. The present paper focuses on the Lower and Upper Members of the Nawata Formation, which are the richest (Table 1). I was able to see the bulk of the material, including all specimens figured by Harris (2003), but there is some material that I could not find, including some specimens whose dimensions were provided by him, and a few cranial pieces mentioned in his descriptions of K. presigmoidalis. However, from the catalogue, other missing fossils are unlikely to include important specimens. Comparisons with material from other sites in Kenya were conducted in the KNM; other relevant comparative material was examined in several institutions, mainly the Muséum National d'Histoire Naturelle, Paris (MNHN), National Museum of Ethiopia, Addis Ababa (NME), and Natural History Museum, London (NHMUK).

In the descriptions, tooth-rows are supposed to be horizontal. Divergence of the horncores is that of their main axes at the base, in front view. Their inclination is the angle between their posterior border and the top of the braincase, in lateral view. Measurements are in mm. Open nomenclature follows Bengtson (1988). 3D reconstructions of Supplemental material C and D were prepared with Agisoft Photoscan TM.

\section{Systematic Palaeontology}

Family Bovidae Gray, 1821

Subfamily Bovinae Gray, 1821

Tribe Boselaphini Knottnerus-Meyer, 1907

Genus Tragoportax Pilgrim, 1937 ?

Tragoportax? sp.

(Fig. 1C)

Remarks. Harris (2003) identified three species of Boselaphini at Lothagam, a larger form and two smaller ones. All of them have horn-cores whose divergence is weak at the base and 
decreases upwards, with a strong anterior keel and a less acute posterolateral one. There is in fact no compelling evidence for more than one species, as members of the Tragoportax group are known to be strongly dimorphic, females being even sometimes hornless (Spassov \& Geraads 2004); for instance, KNM-LT-24214 (Harris 2003, fig. 11.7) taken as representing a small species, has small horn-cores relative to the braincase, and is almost certainly female. The same is true of KNM-LT-195 and KNM-LT-196 (Tragoportax sp. B of Harris 2003), whose relatively small horn cores are inserted wide apart on broad frontals. Differences within Lothagam boselaphins are smaller than at Sahabi, Libya (compare Thomas 1979, pl.1, fig.5, with Gentry 2008, fig. 1). A possible exception is the frontlet KNM-LT-23149 that has long, relatively slender horn cores; it was assigned to T. aff. cyrenaicus by Harris (2003) and Bibi (2011) but its horn cores, like those of the other Lothagam specimens, are definitely less divergent than in this species. Pending the discovery of more specimens (especially cranial) that would better document the variation at Lothagam and elsewhere, I tentatively assign the whole Lothagam material to a single species.

It much differs from 'Mesembriportax' acrae Gentry, 1974 (transferred to Miotragocerus by Gentry 2010) from Langebaanweg, South-Africa, which has very divergent horn cores that are usually short, stout at the base but become cylindrical higher up, thus showing a change in cross-section that is better indicated than at Lothagam. The Lothagam form also differs from Miotragocerus cyrenaicus Lehmann and Thomas, 1987, from Sahabi and the Baynunah Formation of Abu Dhabi (Gentry 1999), in its much less divergent horncores. In the cross section, moderately indicated anterior demarcation, divergence, and course of the horn cores, most Lothagam horn cores (except perhaps KNM-LT-23149) are instead similar to those of Tragoportax abyssinicus Haile-Selassie, Vrba and Bibi, 2009, from the Kuseralee Member of the Sagantole Formation at Amba, Middle Awash, Ethiopia, and the type specimen of the Ethiopian species (Haile-Selassie, Vrba and Bibi, 2009, fig. 9.1) resembles KNM-LT-24214. The slight differences noted by the latter authors can probably be accommodated within intra-specific variation, as members of this group display significant shape variations, as noted as early as in the $19^{\text {th }}$ century (Spassov \& Geraads 2004, and refs therein). However, KNM-LT-23149 differs more from T. abyssinicus, and identification of the whole Lothagam sample with this species would be risky. I also prefer to leave open the genus identification, because some of the characters of the best specimen, KNM-LT-24214 (depressed, rough fronto-parietal area, general shape of the horn-cores) fit Tragoportax, whereas some others (high occipital, median keel on the basioccipital) agree better with Miotragocerus. 
Several dental remains were assigned to this tribe by Harris (2003), but their identification is not straightforward (see Supplemental material B). Some of them definitely do not belong here (such as the maxilla KNM-LT-13012 that has a far too small P4 for this tribe) but other specimens are of more uncertain attribution. On the relatively complete mandibles KNM-LT-203 and KNM-LT-204 (both from the right side; Fig. 1L-N) the pattern of the occlusal surface is suitable for a boselaphin, but the molars are rather hypsodont, and the premolars are much shorter than in T. abyssinicus from Amba (Haile-Selassie et al. 2009, fig. 9.4), M. cyrenaicus from Sahabi (Lehmann \& Thomas 1987, fig. 1A), M. acrae from Langebaanweg (Gentry 1974, fig. 10, table 1), or late Miocene European forms (e.g., Spassov \& Geraads 2004; Kostopoulos 2009a). Rather than assuming a shortening of the premolar row, which is unknown in related forms, I prefer to exclude these specimens from the Boselaphini.

Of the horn cores included by Harris (2003) in the Boselaphini, the only re-identified piece is KNM-LT-23980 that is probably reduncin.

A partial mandible with p4-m1 KNM-LT-26068, accessioned as from the Kaiyumung Member, was listed among the Reduncini by Harris (2003), but is definitely boselaphin in its large $\mathrm{p} 4$ relative to $\mathrm{m} 1$ and absence of goat fold (Fig. 1C). Given the absence of boselaphins in African contemporaneous sites, especially Kanapoi, I regard this stratigraphic origin as unlikely. Thus, the last definite occurrence of this tribe at Lothagam is in the Apak Member (horn-cores KNM-LT-23662 and KNM-LT-24021, as noted by Harris [2003]).

Tribe Tragelaphini Blyth, 1863

Genus Tragelaphus Blainville, 1816

Tragelaphus cf. kyaloi Harris, 1991

Remarks. Not much can be added to the description of this rare species by Harris (2003). The size and degree of anteroposterior compression of the few Lothagam horn-cores (only one of them from the Nawata Formation) are similar to those of $T$. kyaloi from Kanapoi whence it is best known, and intermediate between those of T. moroitu and T. saraitu (Haile-Selassie et al. 2009; Geraads et al. 2009a) but their cross-section is less distinctly triangular than in these Ethiopian forms. They are also more anteroposteriorly compressed than those of the $T$. cf. spekei from Lukeino, Kenya (Thomas 1980), or Tragelaphus sp. from Langebaanweg (Gentry 1980), which are likely to be early representatives of the moroitu-saraitu-rastafari-nakuae 


\section{lineage, and T. kyaloi can be kept as a separate species, a distinction confirmed by its peculiar}

cranial shape (Geraads \& Bobe, in press).

Tribe Bovini Gray, 1821

Bovini gen. et sp. indet.

Remarks. Harris (2003) listed several dental bovin remains from the Nawata Formation, but I could find none of them in the KNM. Bibi (2009) surmised that these teeth are too derived for confidently accepting their stratigraphic origin; on the basis of the photographs provided by him, I definitely agree.

Sub-family Antilopinae Gray, 1821

Tribe Reduncini Knottnerus-Meyer, 1907

Genus Kobus A. Smith, 1840 ?

Kobus ? presigmoidalis Harris, 2003

(Fig. 1E-H)

Description and comparisons. The best specimens of this species are the holotype partial cranium KNM-LT-189, and a similar frontlet KNM-LT-212, both from the Upper Nawata Member, but KNM-LT-486 establishes the occurrence of the species as early as the Lower Nawata Member. Unfortunately, a number of specimens listed by Harris (2003) could not be found in the KNM: these are KNM-LT-497 and KNM-LT-26575 from the Lower Nawata, and KNM-LT-233, KNM-LT-483, KNM-LT-496, KNM-LT-23661, KNM-LT-23713, KNMLT-25951, and KNM-LT-25984 from the Upper Nawata. Some other specimens listed by him have large frontal sinuses and are probably not reduncin, such as KNM-LT-13009, KNM-LT224, and KNM-LT-23671. Although not all reduncin specimens are identifiable to species, $K$. ? presigmoidalis seems to be an uncommon species at Lothagam. It is more clearly reduncin than 'K.' laticornis, discussed farther down, in the lack of frontal pneumatization, general course of the horn-cores, and extremely strong anterior tuberosities of the basioccipital.

Its main characters are: high and narrow occipital, narrow mastoid exposure (like K. sigmoidalis from the Turkana basin), supra-orbital foramina rather small for a reduncin, small postcornual fossa, extremely prominent anterior tuberosities of the basioccipital, horncores not very long, inserted uprightly and moderately curved backwards, with a hint of 
sigmoid curvature, basal divergence moderate, and cross-section transversely compressed with a long axis moderately angled in respect to the sagittal plane.

Harris (2003) described the occipital as broad, but it is in fact distinctly less broad than that of K. subdolus from Langebaanweg (Gentry 1980), in correlation with the more lateral orientation of the mastoid exposure, and these are the main differences with this South African form, which has also thicker, shorter and less compressed horn-cores, and larger supra-orbital foramina. The horn-cores of the Sahabi reduncin (Lehmann \& Thomas 1987; Gentry 2008) are similar to those of the South African form, but more divergent.

Several dentitions from both members of the Nawata Formation are probably reduncin; the lower molars KNM-LT-23624, KNM-LT-23655, and KNM-LT-26052 have goat folds, but the lateral lobes are less rounded than in typical reduncins, and the lingual wall is more heavily folded (Fig. 1E-H). They resemble the teeth from Lukeino assigned to Kobus by Thomas (1980), and it is reasonable to associate them with cranial elements of K. presigmoidalis. The premolars KNM-LT-26007 also resemble those of the ?Hydaspicobus cf. auritus of Pilgrim (1939), from the Siwalik Dhok Pathan Formation.

Remarks. Vrba (in Vrba \& Haile-Selassie 2006, and in Haile-Selassie et al. 2009) thought that $K$. presigmoidalis was identical with the kob from the Kenyan sites of Mpesida and Lukeino, which Thomas (1980) described as Kobus aff. porrecticornis and regarded as identical with other Siwalik forms. Haile-Selassie et al. (2009) also described the species from the earliest Pliocene of the Middle Awash. In addition, an antelope from Baard's Quarry at Langebaanweg was described by Gentry (1980) as K. ?porrecticornis, and another one from Manonga, Tanzania, as K. aff. porrecticornis by Gentry (1997). All these reports suggest a wide distribution of this species or a closely related one (e.g., Bibi 2011). This is questionable, because it may be that these forms are mostly united by the lack of distinctive features, and because the horn core cross section significantly differs between them (virtually circular in 'Indoredunca' theobaldi [Pilgrim 1939, pl. 3, fig. 10], more convex laterally than medially in the type of 'Dorcadoxa' porrecticornis [Pilgrim 1939, pl. 1, fig. 9], laterally flattened at Lothagam) and I prefer to keep calling the Lothagam material $K$. ? presigmoidalis.

The early Pliocene of the Middle Awash Valley yielded other species assigned to the Reduncini, namely Zephyreduncinus oundagaisus Vrba and Haile-Selassie, 2006, Kobus basilcookei Vrba, 2006, Kobus aff. oricornus (see Haile-Selassie et al. 2009), and Redunca ambae Haile-Selassie, Vrba and Bibi, 2009. Distinguishing between all but the first of these taxa is not straightforward; their horn-cores look reduncin in their general course, but unlike in typical reduncins the brain-case is long, the anterior tuberosities of the basioccipital are not 
extremely large, the occipital does not seem to be very broad, and the supra-orbital foraminae are of moderate size (these last two features as in K. presigmoidalis). Haile-Selassie et al. (2009) assigned to R. ambae dentitions said to be similar to those of K. subdolus from Langebaanweg, which Gentry (1980) showed to be morphologically closer to those of tragelaphins, but they also described more typical reduncin dentitions.

In summary, there are clear indications that most of these purportedly early reduncins from Sahabi, Lukeino, and the Middle Awash do not belong to the crown Reduncini. The Langebaanweg $K$. subdolus is also of uncertain position, because of its primitive teeth but reduncin-like broad braincase and large supra-orbital foramina. They all stand in sharp contrast with the typically reduncin cranial parts and dentitions from contemporaneous sites in Chad (Vignaud et al. 2002; Geraads et al. 2009b), suggesting that these early Pliocene East and South African forms are probably representatives of an early radiation of reduncins, and are not members of the clade including the Chadian reduncins + the Reduncini of modern type. By contrast, in spite of its earlier age, Kobus ? presigmoidalis seems to branch higher than $K$. subdolus and might be part of the crown group.

Tribe indet.

Bovidae gen. et sp. indet. A

Remarks. Harris (2003) assigned a few horn-cores to Menelikia leakeyi Harris, 1991, a species defined in the Moiti Member of the Koobi Fora Formation, but also known from more recent strata of the Turkana Basin. Harris' identification was mostly based upon the homonymous torsion of the horn-cores; the best preserved specimens (KNM-LT-178: Harris 2003, fig.11.11; KNM-LT-487) do show it clearly, but other specimens are poorly preserved, and KNM-LT-26026 has an heteronymous torsion and must be of another species. The homonymous horn-cores are too incomplete for definite identification, because homonymous torsion is not exclusive to Menelikia, and because this genus is known only in much younger sediments, and it is safer to remove it from the Lothagam list, although these specimens could be related to it.

'Kobus' laticornis Harris, 2003

Remarks. This species is based upon KNM-LT-180, a partial cranium of large size, with widely divergent, virtually straight horn-cores. A few other specimens were assigned to the 
same species by Harris (2003).Those that can be most confidently identified because they display the same features as the holotype are KNM-LT-199, a horn-core with associated occipital, and KNM-LT-200, a horn-core.

Vrba (2006) questioned the reduncin nature of this species, because on the holotype 1) the anterior tuberosities of the basioccipital are weaker than in reduncins, 2) there is no postcornual fossa, 3 ) the horn-cores have heteronymous torsion, no transverse ridges, but have keels. She noted instead resemblances with the Sahabi boselaphin. Boselaphin affinities can readily be discounted because the keels are far weaker than in this group, but Vrba's points are worth considering, and I may add that the frontals are hollowed by moderate-sized sinuses. All these features are unlike all or most reduncins; some species from Chad also lack transverse ridges and have incipient keels, but they are definitely reduncin in the course of their horn-cores with anterior recurvature distally, thick, solid frontals, and large supra-orbital foramina (Geraads et al. 2001, 2009b). None of the characters of K. laticornis is indeed exclusive of the Reduncini, and I follow Vrba (2006) in rejecting this identification, but alternative tribal assignment is not easy. It is obviously not a member of the Boselaphini, Tragelaphini or Antilopini, while the very likely absence of sinus in the pedicle rule out Alcelaphini or Hippotragini. The incipient frontal pneumatization, great horn-core divergence, and vestigial (?) keels suggest the Bovini, but the small size, and supra-orbital position of the horn-cores go against this. In any case, assignment to a modern tribe is tricky, if not impossible. A new generic name is certainly needed for 'Kobus' laticornis, but knowledge of its anatomy is too incomplete for this name to be really useful.

\section{Bovidae gen. et sp. indet. B}

(Fig. 1D)

Description and comparisons. I assign to this species about 20 specimens from the Nawata Formation (Supplemental material B); they were all included in Aepyceros premelampus by Harris (2003). The best specimen is KNM-LT-26570 from the Lower Nawata (Fig. 1D); it consists of the right side of a braincase with horn-core, probably somewhat distorted by dorsoventral crushing. The occipital is remarkably low and broad, and the braincase itself is broad, with a flat dorsal side. The horn-cores are inserted very far apart and very uprightly (the angle between their posterior border and the top of the braincase is about $100^{\circ}$ ) on solid frontals. They diverge by about $90^{\circ}$ (an angle perhaps augmented by distortion), curve moderately backwards but lack distinct torsion, transverse ridges, and keels. They have an 
incipient triangular cross-section, the degree of outline curvature being greater anteriorly, posterolaterally, and medially, with similar transverse and anteroposterior diameters.

The broad braincase and course of the horn-cores are totally unlike Aepyceros; the lack of frontal sinus and shape of the horn-core are unlike alcelaphins, and no reduncin has similar-shaped horn-cores. The relatively small size and lack of frontal sinuses argue against the Hippotragini, but comparison with late Miocene Chadian forms (Geraads et al. 2008) is relevant here; Tchadotragus has horn-cores with a similar shape and cross-section, and Saheloryx resembles in its broad skull, curvature of the horn-cores, and solid pedicle, but the horn-cores have an oval cross-section. Again, this bovid is too poorly known for its affinities to be firmly established, but it certainly does not easily fit into any of the modern tribes.

Tribe Alcelaphini Brooke in Wallace, 1876

Damalacra Gentry, 1980 ?

Damalacra sp. ?

(Fig. 1I-J)

Description and comparisons. Several alcelaphin teeth, including all those assigned to the Hippotragini by Harris (2003), are accessioned as coming from the Nawata Formation; some of them (KNM-LT-507, KNM-LT-25432, KNM-LT-25960) have a very derived morphology and I suspect that they originate in fact from much younger sediments. The morphology of the remaining teeth is that of primitive alcelaphins; they resemble those of Damalacra from Langebaanweg (Gentry 1980, fig.40), except that the lobes are more evenly rounded buccally (Fig. 1I-J). Of the two horn-cores from the Nawata Formation that Harris (2003) assigned to the Hippotragini, KNM-LT-23709 can be included in the Alcelaphini, and KNM-LT-25968 is probably reduncin. Thus, there is no Hippotragini in the Nawata Formation; the tribe is also quite rare at Kanapoi (Geraads \& Bobe, in press).

Nine basal horn-core pieces, some of them with partial frontals, are tentatively assigned to the Alcelaphini (Supplemental material B), although it may be than more than one species is represented. One of them (KNM-LT-456) was assigned by Harris (2003) to Damalacra, one to Praedamalis (KNM-LT-23709), and three (KNM-LT-13010, KNM-LT23131, and KNM-LT-26037) to Hippotragus. The various identifications of the other specimens can definitely be rejected. By contrast, most of the specimens assigned to Damalacra by Harris (2003) belong to Aepyceros, with the exception of KNM-LT-231, which 
is reduncin, and of a few unidentified (but non-alcelaphin) specimens (Supplemental material B).

These horn-cores are slightly larger and less compressed than the only specimen of D. harrisi Geraads, Bobe and Manthi, 2013 from Kanapoi, and more primitive in their shorter pedicle. They resemble those of Damalacra acalla from Langebaanweg (Gentry 1980) but are smaller than males of this species (Gentry 1980, fig. 39) and more transversely compressed; their divergence does not increase and their diameters remain more constant upwards, so that they do not have the odd shape of D. acalla and many other alcelaphins. These morphological differences bring them closer to the Hippotragini, an identification that would be equally acceptable in regard of the large frontal sinuses extending into the pedicle, but is unlikely because of the strongly arched frontals between the horn-cores (distinctly more so than in the roughly contemporaneous horn-core from Sahabi assigned by Lehmann \& Thomas [1987] to Hippotragus). In addition, no tooth in the Lothagam collection is definitely identifiable as hippotragin, in sharp contrast to the late Miocene of Chad, where primitive hippotragins are abundant (Geraads et al. 2008).

If correctly identified, this alcelaphin is more primitive than the Kanapoi and Langebaanweg Damalacra; it is more like the single basal horn-core from Sahabi assigned to this genus by Lehmann \& Thomas (1987). Other similar horn-cores, from the Kuseralee Member in the Middle Awash, have been described by Haile-Selassie et al. (2009) as Hippotragus sp. The difficulties in telling apart the Alcelaphini and Hippotragini around the Mio-Pliocene transition support a relatively late divergence of these tribes, but the Lothagam material is too incomplete to contribute significantly to this issue.

Tribe Aepycerotini Gray, 1872

Genus Aepyceros Sundevall, 1847

Aepyceros sp.

(Fig. 1A-B)

Remarks. Harris (2003) assigned the majority of Lothagam bovids to his new species Aepyceros premelampus; most of them indeed belong to Aepyceros, but the holotype and paratype are notable exceptions (see below), so that the Lothagam impala, which is relatively common in the Nawata Formation, remains without a species name. Several of the Aepyceros specimens were assigned by Harris (2003) to other taxa, especially Damalacra, as noted above (Supplemental material B). The genus is also present in the Apak and Kaiyumung 
members. Since the best specimen displays no remarkable feature, I prefer not to suggest species identification.

Comparisons. KNM-LT-23673 (Fig. 1A-B) consists of a frontlet and poorly preserved upper part of the braincase. As in the modern A. melampus, the supra-occipital extends far anteriorly on the cranial roof, but is less rectangular. The frontals are distinctly up-arched between the horn-cores, and are much inflated, with small supra-orbital foramina. The braincase KNM-

LT-188 additionally shows that on the basioccipital the posterior tuberosities are less broad than in A. melampus but, as in this species, they are unconnected to the anterior ones by longitudinal ridges. A number of horn-cores differ from modern ones in their simpler course, especially lack of strong increase in divergence shortly above the base; they are not much compressed transversely, and have a rounded cross-section with only an incipient increase of outline curvature postero-laterally, so that the main axis of the cross-section remains almost antero-posterior. In these features, and in size, they resemble early Pliocene fossil impalas from Kanapoi (Geraads et al. 2013; Geraads \& Bobe, in press), the Kuseralee Member in the Middle Awash (Haile-Selassie et al. 2009), Kossom Bougoudi in Chad (Geraads et al. 2009b), and perhaps Mpesida ('Tribu indét.' in Thomas 1980, fig.1.12), but differ from A. afarensis from Woranso Mille (Geraads et al. 2009a) and A. dietrichi from Laetoli (Gentry 2011), which are also distinctly larger (Fig. 2). The course of the horn-cores resemble that of 'Prostrepsiceros' libycus from Sahabi (Lehmann \& Thomas 1987, fig.7), later tentatively referred to their new genus Dytikodorcas by Bouvrain \& Bonis (2007), but the cross-section of the Libyan horn-cores is more compressed, they are grooved anteriorly, and the frontals are not inflated. Several isolated teeth and partial tooth-rows confirm the presence of Aepyceros, but none allows to estimate the premolar/molar index.

Tribe indet.

Afrotragus nov. gen.

Type-species. Aepyceros premelampus Harris, 2003

Diagnosis. That of the single species.

Derivation of name. Afro-, from Africa; -tragus, Greek for goat, often used in bovid names.

Afrotragus premelampus (Harris, 2003)

(Fig. 1L-P; Fig.3; Supplemental material C) 
Types. Harris (2003) designated as holotype of this species the braincase with horn-cores KNM-LT-184, from the Upper Nawata (Harris 2003, fig.11.19; Supplemental material C), and as paratype the cranium KNM-LT-23153 (Fig.3; Harris 2003, fig.11.20), from the Lower Nawata. It is likely that these two specimens are indeed of the same species, but many of the other specimens listed under this name by Harris (2003) belong to several different species, which explains the exceedingly large range of horn-core measurements (Harris 2003, tab. 11.30). In addition, I assign to Afrotragus premelampus several specimens that were listed by him under different names (Supplemental material B).

Diagnosis. Antelopes of medium size. Face slightly inclined on the neurocranium; preorbital fossa present; premaxilla not very broad, but with a distinctly square outline in ventral view; frontals lacking sinuses, supraorbital foramina of medium size; braincase and occipital broad and low; mastoid exposure not very broad; basioccipital with relatively large anterior tuberosities. Horn-cores long and slender, inserted rather upright, without transverse ribs, with a well-marked heteronymous torsion, main axis of the cross-section much angled in respect to the sagittal plane. Upper molars with weak styles, poorly indicated paracone rib, U-shaped central valleys, central enamel island, and seemingly late fusion of the lobes in the central part of the tooth.

Description. The most complete specimen is the imperfectly cleaned cranium KNM-LT23153 (Fig. 3), which displays a number of differences with Aepyceros. It is long and narrow, but the braincase is broad, longer and less inclined in respect to the facial axis than in this genus, and less rounded dorsally. The nasal bones are missing, but were certainly rather narrow, in contrast to Aepyceros. They probably had a shorter contact with the premaxillae than in the impala, and the right side of the skull, well-preserved in this area, shows the absence, between the premaxilla and the maxilla, of the large gap that is a characteristic feature of Aepyceros (modern A. melampus, and Hadar A. datoadeni, the only fossil form in which this area is known). As observed by Gentry (1985), this gap is otherwise present only in Neotragus and Nesotragus, two small antelopes that are regarded as the sister-group of Aepyceros by Hassanin et al. (2012) and Yang et al. (2013): it follows that this gap is not just a synapomorphy of Pliocene to modern Aepyceros, but of this whole group, and its absence in Afrotragus strongly speaks against its inclusion in it.

The most noticeable feature of the premaxillae in KNM-LT-23153 is the square outline of their rostral end, quite distinct from the rounded shape in A. melampus and A. datoadeni; this almost certainly indicates a grazer (compare Fig. 3A with Solounias \& Moelleken 1993, fig. 1), unlike them. Both sides of the face are hollowed by a large ante- 
orbital depression, absent in Aepyceros. The medial part of the frontals are depressed between the orbits and were certainly devoid of sinuses, in contrast to Aepyceros, and the supra-orbital foramina are larger than in this genus. The area of the postcornual fossa is unclear. The mastoid exposure is narrow, and has a much smaller extent on the occipital surface than in the impala. The anterior tuberosities of the basioccipital are strong and somewhat splayed out laterally, and the bone is much broader at this level than in Aepyceros. The horn-cores (Harris 2003, fig. 11.20) are long, with a distinct sigmoid curvature; the main axis of the cross-section is strongly oblique, so that the moderate compression appears antero-posterior.

The premolars are missing, and the molars poorly preserved. They much differ from those of Aepyceros in their greater relative breadth, much weaker styles, more convex paracone pillar buccally, a tendency to pinching of the lingual lobes, and presence of a transversely elongated central enamel island or valley between the lobes, which seem to fuse only late in wear at this level.

The holotype partial skull KNM-LT-184 (Supplemental material C) is generally similar to KNM-LT-23153; it shows additionally that the postcornual fossa, not observable in the complete skull, is well indicated. This specimen differs in the better expressed central groove on the basioccipital, the broader mastoid, and perhaps larger supra-orbital foramina. Similarities outweigh these differences, and I regard them as co-specific, which is also a more parsimonious option.

Several horn-cores with parts of the frontals, all of them from the Nawata Formation, can tentatively be assigned to the same species on the basis of the lyration, very oblique main axis of the cross-section, and depressed frontals lacking pneumatization (Fig. 1O-P). Some dental remains (Fig. $1 \mathrm{~L}-\mathrm{N}$ ) could also belong here, but the teeth of the holotype are too poorly preserved to allow reliable identification of other specimens.

\section{Comparisons. Afrotragus premelampus is unlike most other African bovids, but it does} resemble the 'Prostrepsiceros' libycus from Sahabi (Lehmann \& Thomas 1987; NHMUK M32981 and M32982 are casts of two horn-cores). They share long, slender, spiralled horncores, and a frontal poorly bent anteroposteriorly and lacking sinuses; some Lothagam horncores, especially KNM-LT-219, display an incipient anterior groove, as at Sahabi. The main axis of the cross-section of ' $P$.' libycus horn-cores is oblique in respect to the sagittal plane, but this is mainly due to a strong posterolateral longitudinal ridge, absent at Lothagam; they are also more inclined backwards, and M32981 shows no postcornual fossa, in contrast to KNM-LT-184. The upper teeth share similar characters. Thus, the Sahabi species is conceivably related to Afrotragus premelampus (rather than to Dytikodorcas to which it was 
assigned by Bouvrain \& Bonis 2007, but which is a much smaller form); however, the fact that it is very poorly known, and some differences, preclude identification at species level.

Another possible relative is the 'Aepyceros aff. premelampus' from Lemudong'o (Hlusko et al. 2007), but it is too incompletely preserved for identification.

Afrotragus must also be compared to the late Miocene Eurasian forms of the Prostrepsiceros group (Gentry 1971; Bouvrain 1982; Bouvrain \& Thomas 1992; Kostopoulos 2004, 2006), which is widespread but remains imperfectly known (especially the facial part).

They resemble Afrotragus in their broad occipital, basioccipital usually with a central groove, presence of an ante-orbital depression, horn-cores with heteronymous torsion and much angled main axis of the cross-section, and in their upper molar shape, but they differ in their smaller size, absence of clearly marked longitudinal ridges on either side of the basioccipital (but they are conspicuous on KNM-LT-184 only), narrower mastoid exposure, and especially shorter and stouter horn-cores with tighter spiralling and usual presence of keels (much reduced in P. rotundicornis). The earliest Prostrepsiceros is $P$. vallesiensis Bouvrain, 1982, from the early late Miocene of Greece; it is primitive in its narrow occipital, but derived in its short nasal bones, relatively strong cranial flexure, and early fusion of the molar lobes. It might belong to a group of antelopes known only by horn-cores that resemble those of Afrotragus in being loosely spiralled (in contrast to typical Prostrepsiceros) and whose main axis of the cross section tends to be strongly angled in respect to the sagittal plane. They centre on 'Prostrepsiceros' vinayaki (Pilgrim, 1939) and are known from the Siwaliks (Pilgrim 1939), Afghanistan (Kostopoulos 2009b), the Arabian peninsula (Gentry 1999), Maragha (Kostopoulos \& Bernor 2011), Turkey (Gentry 2003), and the Ethiopian Middle Awash (Bibi 2011). Their horn-cores differ from those of Afrotragus in being smaller, more compressed transversally, and with a tendency to develop anterior and posterior keels but, despite these differences, they might have given rise to this genus, as well as to Prostrepsiceros itself, but no Eurasian species of Prostrepsiceros displays the long, slender horn cores of Afrotragus and, if they share a common ancestor, the divergence must date to the earlier part of the late Miocene.

Tribe indet.

Genus Turkanatragus nov. gen.

Type species. Turkanatragus marymuunguae nov. sp.

Diagnosis. That of the single species. 
Derivation of name. Turkana-, from the Turkana people; -tragus, Greek for goat, often used in bovid names.

\section{Turkanatragus marymuunguae nov. sp.}

(Fig. 4; Supplemental material D)

Holotype. KNM-LT-28752, incomplete braincase with almost complete horn-cores, from the Lower Nawata Member. In spite of a longitudinal crack, it is almost undistorted.

Diagnosis. Frontal little hollowed if at all; long, wide braincase, but mastoid facing mostly laterally; occipital narrow, with both sides facing posterolaterally on either side of a raised central part, top of the occipital produced caudally into a strong process; basioccipital with thick longitudinal ridges; horn-cores slender, with gentle sigmoid curvature and no transverse compression. Differs from Afrotragus in its much longer braincase, distinctly narrower occipital with strong central process and mastoid exposure facing more laterally, and more slender horn-cores.

Derivation of name. Dedicated to Mary Muungu, former chief collections manager at the Palaeontology Section of the KNM, for her invaluable help there.

Comparisons. The holotype was included in Aepyceros premelampus by Harris (2003). It does resemble Aepyceros in the poor cranial flexure, deep postcornual fossa, high, narrow occipital (much narrower than in Afrotragus), and horn-cores with slight sigmoid, heteronymous curvature and no transverse compression. However, it differs from the modern A. melampus and fossil A. datoadeni from Hadar (Geraads et al. 2012) and A. shungurae from Omo (Gentry 1985) in the lack of frontal sinuses, much longer braincase with a poorly convex dorsal outline, and presence of thick ridges connecting the anterior and posterior tuberosities of the basioccipital. In addition, the most remarkable feature of KNM-LT-28752 is the shape of the occipital. The mastoid exposure faces almost completely laterally, and is wider ventrally; the occipital is high and rather narrow, and much decreases in width upwards; both halves of the occipital face posterolaterally on either side of a caudally salient medial part that is ridge-like in its central part, and ends dorsally into a large triangular process, protruding caudally.

I do not formally include any other specimen in this species; some horn cores may belong here, but since there are at least three species of spiral-horned antelopes at Lothagam, identification of every specimen is impossible.

KNM-LT-28752 resembles Afrotragus premelampus in its fronto-parietal area, and general course of its horn-cores (Fig. 4), but differs in their stronger torsion, and especially in 
its occipital, which is much broader and facing wholly caudally in the latter species. The proportions and shape of the occipital may display significant variations in modern forms but none closely resembles KNM-LT-28752. Thus, unless it is a pathological specimen, which is an unsupported assumption, the differences in occipital shape and proportions with

A. premelampus leave no doubt as to their taxonomic distinctness. The only modern occipital reminiscent of the highly characteristic shape of that of KNM-LT-28752 is that of the gerenuk, Litocranius walleri, but in this species the whole dorsal part of the occipital is protruding and, remarkably, the parieto-occipital suture is straight and transverse, in contrast to KNM-LT-28752 that retains the central extension of the supra-occipital into the parietal, which is the usual condition in bovids. Thus, the resemblance between KNM-LT-28752 and the gerenuk is very superficial; it is perhaps linked with a similar head posture (the gerenuk is often bipedal when browsing).

A possible relative of Turkanatragus marymuunguae is the species from Kanapoi that Geraads et al. (2013) and Geraads \& Bobe (in press) called aff. Dytikodorcas sp. (KNM-KP29277). They share a complicated parieto-frontal suture, a long braincase, an occipital that is quite narrow dorsally with at least some caudal expansion medially (broken off in KNM-KP29277), and horn-cores with some heteronymous curvature; the main difference is that KNMKP-29277 has a transversely compressed horn-core. Both specimens are too incomplete for definite conclusions about their relationships but, along with Aepyceros, Afrotragus and the Sahabi 'Prostrepsiceros', they attest to the diversity of spiral-horned taxa in the late Miocene of Africa.

Tribe Antilopini Gray, 1821

Genus Gazella Blainville, 1816 ?

Gazella sp. ?

Remarks. KNM-LT-13008, assigned to Gazella by Harris (2003), has a large frontal sinus and is probably alcelaphin. By contrast, the basal horn-core KNM-LT-23736 assigned by him to Damalacra lacks a frontal sinus and better fits Gazella, of which it would document a rather large species. KNM-LT-463 has a small frontal sinus anterior to the supra-orbital foramen and also better fits Gazella s.1. KNM-LT-22990 is a mandible with dp2-m2, possibly also of Gazella. KNM-LT-503 is a lower $\mathrm{m} 1(\mathrm{~L}=10.9)$ that was the only Nawata specimen assigned to Raphicerus by Harris (2003) but is larger than the fossils assigned below to this genus, and its size corresponds to that of Gazella s.l. 
The mandible KNM-LT-23599 (Fig. 1K) is puzzling; it is Aepyceros-like in morphology, but the premolars are too short for this genus. They are even shorter than in modern Ourebia; in addition, the central valleys of the molars are shorter than in the oribi, and the hypoconid of $\mathrm{p} 4$ is less clearly demarcated from the protoconid. It was assigned by Harris (2003) to Gazella, but might as well belong to one of the spiral-horned Lothagam antelopes.

Genus Raphicerus H. Smith, 1827 ?

Raphicerus sp. ?

A few dental remains assigned by Harris (2003) to Madoqua are too large for this genus, but could belong to Raphicerus or a related form; those from the Nawata Formation are: KNM-LT-177, KNM-LT-22981, KNM-LT-23612, and KNM-LT-28733.

\section{The Late Miocene diversification of African Bovidae}

The Nawata Formation of Lothagam and the roughly contemporaneous sites of Toros Menalla in Chad have yielded the only large bovid assemblages from the late Miocene of Africa, contemporaneous with European Turolian faunas. They are thus critical, along with the much less diverse assemblages of Sahabi, Libya (Lehmann \& Thomas 1987; Gentry 2008), Lemudong'o (Hlusko et al. 2007) and Lukeino (Thomas 1980), Kenya, to reconstruct the early history of some of the present-day African tribes, the Tragelaphini of the subfamily Bovinae and, in the subfamily Antilopinae, the sister-tribes Hippotragini and Alcelaphini, the more distantly related Reduncini, and the enigmatic Aepycerotini, which recent genetic analyses (Hassanin et al. 2012; Yang et al. 2013) place at a basal position within this subfamily. It should be noted that these genetic analyses, their major discrepancies aside, have shown that the classical tribes have very unequal status in a phylogenetic taxonomy, most of them being paraphyletic; for instance, the (Aepycerotini + Neotragini) clade branches as the sister-group of all other Antilopinae (Hassanin et al. 2012; Yang et al. 2013; but see Decker et al. 2009), whereas the Alcelaphini-Hippotragini divergence occurs very high in the tree.

In recent studies, all late Miocene to modern African bovids have been assigned, even if tentatively, to these modern tribes. However, even previous to the present revision of the Lothagam material, some fossils suggested the presence, in the Late Miocene of Africa, of 
taxa that could not be easily assigned to the crown groups of these various tribes. Indeed, as observed by Bibi (2013:10), '... in almost all cases, the stem branches leading to these originations [of the crown groups] are long, stretching back to the middle Miocene, which makes it possible that their late Miocene "radiation" is actually an artefact of differential (nonrandom) extinction of older lineages.' For instance, Geraads et al. (2008) assigned Saheloryx solidus from Toros-Menalla in Chad to the Hippotragini because its teeth could not be told apart from those of Tchadotragus, but it lacks some of the derived features of the modern forms, and is certainly not a member of the crown Hippotragini. The case of the Reduncini is extreme; Bibi (2013) estimates their divergence at ca. 14 Ma, before the splits within the Caprini-Hippotragini-Alcelaphini clade, but the crown Reduncini are not much older than 5 Ma. Thus, it is likely that some, or many, of the early reduncins were not members of the crown-group, making them hard to identify on the basis of the characters of the modern forms. Kobus ? presigmoidalis, many of the late Miocene to early Pliocene 'Kobus', and the various forms centred on K. porrecticornis are probably such early offshoots.

Fossils cannot falsify a phylogeny based upon genetics of modern taxa, but there is no reason to forcefully include fossil taxa into a taxonomy based upon this phylogeny, unless they display features of the crown groups. As shown above, several of the Lothagam bovids do not fit into the modern tribal arrangement. Tragelaphus kyaloi much differs from modern tragelaphins in the shape of its braincase (Geraads \& Bobe, in press) but can reasonably be regarded as a stem tragelaphin, as it shares some of the horn-core and dental characters of this tribe. By contrast, 'Kobus' laticornis fails to display any clear reduncin character, but is too poorly represented for assignment to another (new ?) tribe. The Bovidae gen. et sp. indet. A and $\mathrm{B}$, described above, are also of uncertain position because they are poorly known, and at least the latter one does not easily fit into a modern tribe. The newly recognized spiral-horned Lothagam antelopes, Afrotragus and Turkanatragus, are better represented. Each of them display sets of characters that are quite unlike those of any of the crown-groups, and assignment to any existing tribe would be unsupported; a phylogenetic analysis might reveal the need for a new tribe to which the incompletely known Turkanatragus could also belong, as suggested by the shape of its horn-cores. Together with the 'Prostrepsiceros' libycus from Sahabi, they document the occurrence, in the late Miocene of Africa, of several spiral-horned antelopes that might belong to a single group. In spite of a similar course of the horns, they are unrelated to Aepyceros, and putting them in the Antilopini, together with Prostrepsiceros, merely reflects the lack of characters that define the present-day African tribes, in agreement with the basal position of the 'Antilopini' relative to them. 
As discussed in Supplemental material A, the Lothagam bovid fauna and its spiralhorned antelopes have no clear ancestors in the first part of the African Late Miocene, but it may be that the dearth of sites of Vallesian-equivalent age in this continent hampers their recognition. By contrast, the North Tethysian realm has a number of spiral-horned antelopes among which it is tempting to search for the ancestors of the Lothagam forms. I shall leave the issue open but, if true, this biogeographic history would be shared by several other large mammals that may have dispersed into Africa at roughly the same period, e.g., Dinocrocuta, Giraffa, Ancylotherium, Ceratotherium, perhaps Kolpochoerus-Dasychoerus; some people even list hominins. Remarkably, these spiral-horned antelopes all vanish shortly after Nawata Formation times, as they are absent from the Nachukui Formation and from Kanapoi.

\section{Conclusion}

Today, the Bovidae are by far the most diverse group of large African ungulates, but it seems that this great modern diversity, by comparison with other groups, led researchers to regard it as representative of the whole history of the family. The Lothagam fossil record shows that it may have been still greater in the past, not because of a greater number of individual species, but because of the existence of genera not belonging to the crown groups, which could even attest to the presence of tribes that are now wholly extinct and remain hidden in classifications based upon modern taxa. The Eurasian radiation at roughly the same time-period also led to the appearance of numerous genera that are usually tentatively regarded as close to one of the modern tribes, but might as well belong to extinct groups warranting tribal status.

\section{Acknowledgments}

Thanks to all people who allowed me to access modern and fossil collections in their care during the last decades, or provided photos: C. Argot and J. Lesur (MNHN), F. Bibi (Humboldt University, Berlin), P. Brewer and A. Currant (NHMUK), L. Dumouchel (George Washington University), D.S. Kostopoulos (Aristotle University of Thessaloniki), R. Manni (University of Rome), M.G. Leakey, F. K. Manthi, E. Mbua, M. Muungu (KNM), A. Prieur (Claude Bernard University, Lyon), and G. Senichaw (NME). The manuscript greatly benefited from the comments of three anonymous reviewers. 


\section{References}

Bengtson, P. 1988. Open nomenclature. Palaeontology, 31, 223-227.

Bibi, F. 2009. Evolution, Systematics, and Paleoecology of Bovinae (Mammalia:

Artiodactyla) from the Late Miocene to the Recent. Ph.D. Thesis, Yale University, Geology and Geophysics, 469 pp.

Bibi, F. 2011. Mio-Pliocene Faunal Exchanges and African Biogeography: The Record of Fossil Bovids. PLoS ONE, 6(2), e16688. Doi:10.1371/journal.pone.0016688

Bibi, F. 2013. A multi-calibrated mitochondrial phylogeny of extant Bovidae (Artiodactyla, Ruminantia) and the importance of the fossil record to systematics. BMC Evolutionary Biology, 13, 166.

Bibi, F., Bukhsianidze, M., Gentry, A. W., Geraads, D., Kostopoulos, D. S. \& Vrba, E. 2009. The Fossil Record and Evolution of Bovidae: State of the Field. Palaeontologia Electronica, 12(3), 1-11.

Blainville, H. M. D. de 1816. Prodrome d'une nouvelle distribution systématique du règne animal. Bulletin des sciences, Société philomathique, 3, 105-124.

Blyth, E. 1863. Catalogue of the Mammalia in the Museum of the Asiatic Society of Bengal. Savielle and Cranenburgh, Calcutta, 187 pp.

Bouvrain, G. 1982. Révision du genre Prostrepsiceros Major, 1891 (Mammalia, Bovidae). Paläontologische Zeitschrift, 56, 113-124.

Bouvrain, G. \& Bonis, L. de 2007. Ruminants (Mammalia, Artiodactyla: Tragulidae, Cervidae, Bovidae) des gisements du Miocène supérieur (Turolien) de Dytiko (Grèce). Annales de Paléontologie, 93, 121-147.

Bouvrain, G. \& Thomas, H. 1992. Une antilope à chevilles spiralées : Prostrepsiceros zitteli (Bovidae). Miocène supérieur du Jebel Hamrin en Irak. Geobios, 25, 525-533.

Decker J. E., Pires, J. C., Conant, G. C., McKay, S. D., Heaton, M. P., Chen, K., Cooper, A., Vilkki, J., Seabury, C. M., Caetano, A. R., Johnson, G. S., Brenneman, R. A., Hanotte, O., Eggert, L. S., Wiener, P., Kim, J.-J., Kim, K. S., Sonstegard, T. S., Van Tassell, C. P., Neibergs, H. L., McEwan, J. C., Brauning, R., Coutinho, L. L., Babar, M. E., Wilson, G. A., McClure, M. C., Rolf, M. M., Kim, J., Schnabel R.

D. \& Taylor, J. F. 2009. Resolving the evolution of extant and extinct ruminants with high-throughput phylogenomics. Proceedings of the National Academy of Sciences of the USA, 106, 18644-18649. 
Drapeau, M., Bobe, R., Wynn, J., Campisano, C., Dumouchel, L. \& Geraads, D. 2014. The Omo Mursi Formation: a window into the East African Pliocene. Journal of Human Evolution, 75, 64-79.

Feibel, C. S. 2003. Stratigraphy and depositional history of the Lothagam sequence. Pp. 1729 in M. G. Leakey \& J. M. Harris (eds) Lothagam: the dawn of humanity in Eastern Africa. Columbia University Press, New York.

Gentry, A. W. 1971. The earliest goats and other antelopes from the Samos Hipparion fauna. Bulletin of the British Museum (Natural History) Geology, 20, 231-296.

Gentry, A. W. 1974. A new genus and species of Pliocene Boselaphine (Bovidae, Mammalia) from South Africa. Annals of the South African Museum, 65, 145-188.

Gentry, A. W. 1980. Fossil Bovidae (Mammalia) from Langebaanweg, South Africa. Annals of the Transvaal Museum, 79, 213-337.

Gentry, A. W. 1985. The Bovidae of the Omo deposits, Ethiopia. Pp. 119-191 in Y. Coppens \& F. C. Howell (eds) Les faunes plio-pléistocènes de la basse vallée de l'Omo (Ethiopie). Cahiers de Paléontologie, Travaux de paléontologie est-africaine. Centre National de la Recherche Scientifique, Paris.

Gentry, A. W. 1997. Fossil Ruminants (Mammalia) from the Manonga Valley, Tanzania. Pp. 107-135 in T. Harrison (ed) Neogene Paleontology of the Manonga Valley, Tanzania. Topics in Geobiology, 14. Plenum Press, New York.

Gentry A. W. 1999. Fossil pecorans from the Baynunah Formation, Emirate of Abu Dhabi, United Arab Emirates. Pp. 290-316 in P. J. Whybrow \& A. Hill (eds) Fossil Vertebrates of Arabia. Yale University Press, New Haven.

Gentry A. W. 2003. Ruminantia (Artiodactyla). Pp. 332-379 in M. Fortelius, J. Kappelman, S. Sen \& R. L. Bernor (eds) Geology and Paleontology of the Miocene Sinap Formation, Turkey. Columbia University Press, New York.

Gentry, A. W. 2008. New records of Bovidae from the Sahabi Formation. Garyounis Scientific Bulletin, special issue, 5, 205-217.

Gentry, A. W. 2010. 38. Bovidae. Pp. 741-796 in L. Werdelin \& W. J. Sanders (eds) Cenozoic Mammals of Africa. University of California Press, Berkeley.

Gentry, A. W. 2011. 15. Bovidae. Pp. 363-465 in T. Harrison (ed) Paleontology and Geology of Laetoli: Human Evolution in Context, vol. 1. Springer, New York.

Geraads, D. \& Bobe, R. In press. Ruminants (Bovidae and Giraffidae) from Kanapoi. Journal of Human Evolution. 
Geraads, D., Brunet, M., Mackaye, H. T. \& Vignaud, P. 2001. Pliocene Bovidae from the Koro Toro Australopithecine sites, Chad. Journal of Vertebrate Paleontology, 21, 335-346.

Geraads, D., Blondel, C., Likius, A., Mackaye, H.T., Vignaud, P. \& Brunet, M., 2008. New Hippotragini (Bovidae) from the late Miocene of Toros-Menalla, Chad. Journal of Vertebrate Paleontology, 28, 231-242.

Geraads, D., Melillo, S. \& Haile-Selassie, Y. 2009a. Middle Pliocene Bovidae from Hominid-bearing sites in the Woranso-Mille area, Afar region, Ethiopia. Palaeontologia Africana, 44, 59-70.

Geraads, D., Blondel, C., Mackaye, H.T., Likius, A., Vignaud, P. \& Brunet, M. 2009b. Bovidae (Mammalia) from the lower Pliocene of Chad. Journal of Vertebrate Paleontology, 29, 923-933.

Geraads, D., Bobe, R. \& Manthi, F. K. 2013. New ruminants (Mammalia) from the Pliocene of Kanapoi, Kenya, and a revision of previous collections, with a note on the Suidae. Journal of African Earth Sciences, 85, 53-61.

Geraads, D., Bobe, R. \& Reed, K. 2012. Pliocene Bovidae (Mammalia) from the Hadar Formation of Hadar and Ledi-Geraru, Lower Awash, Ethiopia. Journal of Vertebrate Paleontology, 32, 180-197.

Gray, J. E. 1821. On the natural arrangment of vertebrose animals. London Medical Repository, 15, 296-310.

Gray, J. E. 1872. Catalogue of the ruminant Mammalia (Pecora, Linnaeus) in the British Museum. Trustees of the British Museum, London, $102 \mathrm{pp}$.

Haile-Selassie, Y., Vrba, E. S. \& Bibi, F. 2009. 9. Bovidae. Pp. 277-330 in Y. HaileSelassie \& G. Woldegabriel (eds) Ardipithecus kadabba - Late Miocene Evidence from the Middle Awash, Ethiopia. University of California Press, Berkeley.

Harris, J. M. 1991. Family Bovidae. Pp. 139-320 in J. M. Harris (ed) Koobi Fora Research Project. Volume 3: The fossil ungulates: Geology, Fossil artiodactyls and palaeoenvironments. Clarendon Press, Oxford.

Harris, J. M. 2003. Bovidae from the Lothagam succession. Pp. 531-582 in M. G. Leakey \& J. M. Harris (eds) Lothagam: the dawn of humanity in Eastern Africa. Columbia University Press, New York.

Hassanin, A., Delsuc, F., Ropiquet, A., Hammer, C., Jansen van Vuuren B., Matthee, C., Ruiz-Garcia M., Catzeflis F., Areskoug, V., Nguyen T.T., Couloux, A. 2012. Pattern and timing of diversification of Cetartiodactyla (Mammalia, Laurasiatheria), as 
revealed by a comprehensive analysis of mitochondrial genomes. Comptes Rendus Biologies, 335, 32-50.

Hlusko, L. J., Haile-Selassie, Y. \& DeGusta, D. 2007. Late Miocene Bovidae (Mammalia: Artiodactyla) from Lemudong'o, Narok district, Kenya. Kirtlandia, 56, 163-172.

Knottnerus-Meyer, T. 1907. Über das Tränenbein der Huftiere. Vergleichend-anatomischer Beitrag zur Systematik der rezenten Ungulata. Archiv für Naturgeschichte, 73, 1-152.

Kostopoulos, D. S. 2004. Revision of some late Miocene spiral horned antelopes (Bovidae, Mammalia). Neues Jahrbuch für Geologie und Paläontologie Abhandlungen, 231, $167-190$

Kostopoulos, D. S. 2006. The late Miocene vertebrate locality of Perivolaki, Thessaly, Greece.9. Cervidae and Bovidae. Palaeontographica, 276, 151-183.

Kostopoulos, D. S. 2009a. The late Miocene Mammal faunas of the Mytilinii Basin, Samos Island, Greece: new collection. 14. Bovidae. Beiträge zur Paläontologie, 31, 345-389.

Kostopoulos, D. S. 2009b. Contribution to the systematics and phylogeny of Prostrepsiceros vallesiensis Bouvrain, 1982 (Mammalia, Bovidae). Geodiversitas, 31, 879-891.

Kostopoulos, D. S. \& Bernor, R. L. 2011. The Maragheh bovids (Mammalia, Artiodactyla): Systematic revision and biostratigraphic-biozoogeographic interpretation. Geodiversitas, 33, 649-708.

Leakey, M. G. 2003. Introduction. Pp.1-14 in M. G. Leakey \& J. M. Harris (eds) Lothagam: the dawn of humanity in Eastern Africa. Columbia University Press, New York.

Leakey, M. G. \& Harris, J. M. 2003. Lothagam: the dawn of humanity in Eastern Africa. Columbia University Press, New York, 678 pp.

Lehmann, U. \& Thomas, H. 1987. Fossil Bovidae (Mammalia) from the Mio-Pliocene of Sahabi, Libya. Pp. 323-335 in N.T. Boaz, A. El-Arnauti, A. W. Gaziry, J. de Heinzelin, \& D.D. Boaz (eds) Neogene Paleontology and Geology of Sahabi. Alan R. Liss, New York.

McDougall, I. \& Feibel, C. S. 2003. Numerical age control for the Miocene-Pliocene succession at Lothagam, a Hominoid-bearing sequence in the northern Kenya Rift. Pp.43-64 in M. G. Leakey \& J. M. Harris (eds) Lothagam: the dawn of humanity in Eastern Africa. Columbia University Press, New York.

Pilgrim, G. E. 1937. Siwalik antelopes and oxen in the American Museum of Natural History. Bulletin of the American Museum of Natural History, 72, 729-874.

Pilgrim, G. E. 1939. The Fossil Bovidae in India. Memoirs of the Geological Survey of India 26, $1-356$. 
Smith, A. 1840. Illustrations of the zoology of South Africa. Smith, Elder and co., London, 52 pl.

Solounias, N. \& Moelleken, S. M. C. 1993. Dietary adaptation of some extinct ruminants determined by premaxillary shape. Journal of Mammalogy, 74, 1059-1071.

Spassov, N. \& Geraads, D. 2004. Tragoportax Pilgrim and Miotragocerus Stromer (Mammalia, Bovidae) from the Turolian of Hadjidimovo, Bulgaria, and a revision of the Late Miocene Mediterranean Boselaphini. Geodiversitas, 26, 339-370.

Sundevall, C. J. 1847. Methodisk Ofversigt af Idislande djuren, Linnes Pecora. Kungliga vetenskapsakademiens handlingar, 2, 1-330.

Thomas, H. 1979. Miotragocerus cyrenaicus sp. nov. (Bovidae, Artiodactyla, Mammalia) du Miocène supérieur de Sahabi (Libye) et ses rapports avec les autres Miotragocerus. Geobios, 12, 267-281.

Thomas, H. 1980. Les bovidés du Miocène supérieur des couches de Mpesida et de la Formation de Lukeino (district de Baringo, Kenya). Pp. 82-91 in R. E. Leakey \& B. Ogot (eds) Actes du $8^{\circ}$ Congrès Panafricain de Préhistoire et des Etudes du Quaternaire, Nairobi.

Vignaud, P., Duringer, P., Mackaye, H. T., Likius, A., Blondel, C., Boisserie, J.-R, Bonis, L. de, Eisenmann, V., Etienne, M.-E., Geraads, D., Guy, F., Lehmann, T., Lihoreau, F., Lopez-Martinez, N., Mourer-Chauviré, C., Otero, O., Rage, J.-C., Schuster, M., Viriot, L., Zazzo, A. \& Brunet, M. 2002. Geology and Palaeontology of the Upper Miocene Toros-Menalla hominid locality, Chad. Nature, 418, 152-155.

Vrba, E. S. 2006. A possible ancestor of the living waterbuck and lechwes: Kobus basilcookei sp. nov. (Reduncini, Bovidae, Artiodactyla) from the Early Pliocene of the Middle Awash, Ethiopia. Transactions of the Royal Society of South Africa, 61, 63-74.

Vrba, E. S. \& Haile-Selassie, Y. 2006. A new antelope, Zephyreduncinus oundagaisus (Reduncini, Artiodactyla, Bovidae) from the late Miocene of the Middle Awash, Afar rift, Ethiopia. Journal of Vertebrate Paleontology 26, 213-218.

Wallace, A. R. 1876. The geographical distribution of animals. Macmillan and Co., London, $503+607 \mathrm{pp}$.

Yang, C., Xiang, C., Qi, W., Xia, S., Tu, F., Zhang, X., Moermond, T. \& Yue, B. 2013. Phylogenetic analyses and improved resolution of the family Bovidae based on complete mitochondrial genomes. Biochemical Systematics and Ecology, 48, 136-143. 
Figure 1. A-B, Aepyceros sp., frontlet KNM-LT-23673 (A, close-up of the frontals; B, anterodorsal view); C, Tragoportax ? sp., left tooth-row p4-m2 KNM-LT-26068; D, Bovidae gen. et sp. indet. B, right lateral view of horn-core with braincase KNM-LT-26570; E-H, Reduncini ? (Kobus ? presigmoidalis ?); E, right m1-m3 KNM-LT-23624, occlusal view; FG, m3 KNM-LT-26052 (F, occlusal view; G, buccal view); H, left m2-m3 KNM-LT-23655, occlusal view; I-J, Damalacra sp. ?, mandible fragment with $\mathrm{m} 1$ and partial $\mathrm{m} 2 \mathrm{KNM}-\mathrm{LT}$ 235 (I, lingual view; J, occlusal view); K, Bovidae gen. et sp. indet. (Gazella ?), left mandible with p2-m3 KNM-LT-23599, occlusal view; L-N, Afrotragus premelampus ?; L-M, right mandible KNM-LT-204 (L, occlusal view; M, lingual view); N, right mandible KNM-LT203, occlusal view; O-P, Afrotragus premelampus, left horn-core with frontal KNM-LT-185 (O, lateral view; P, front view). Scale bar equals $20 \mathrm{~cm}$ for Figs. B and O-P, $10 \mathrm{~cm}$ for Figs. $\mathrm{A}$ and $\mathrm{D}, 5 \mathrm{~cm}$ for all others.

Figure 2. Plot of basal diameters of Aepyceros horn-cores: Aepyceros sp. from Omo Mursi Formation (Gentry 1985, Drapeau et al. 2014); Aepyceros datoadeni from Hadar (Geraads et al. 2012); Aepyceros afarensis from Woranso-Mille (Geraads et al. 2009a); Aepyceros cf. afarensis from Kanapoi (Geraads \& Bobe, in press); Aepyceros dietrichi from Laetoli (Gentry 2011, and original measurements); Aepyceros sp. from the Nawata Formation of Lothagam.

Figure 3. Afrotragus premelampus cranium KNM-LT-23153. A, dorsal view; B, occipital view; $\mathbf{C}$, ventral view; D, occlusal view of M2-M3; E, right lateral view. Scale bar equals 5 $\mathrm{cm}$ for Fig. D, $10 \mathrm{~cm}$ for all others.

Figure 4. Turkanatragus marymuunguae, holotype KNM-LT-28752. A, left lateral view; B, front view. Scale bar equals $20 \mathrm{~cm}$.

\section{Supplemental material}

Supplemental material A. Additional notes on the Bovidae from the Apak and Kaiyumung Members, and on the origin of the Lothagam bovid fauna.

Supplemental material B. Catalogue of the Lothagam Bovidae, with previous and revised identifications, and main measurements. 
1 Supplemental material C. 3D reconstruction of KNM-LT-184, holotype of Afrotragus 2 premelampus (Harris, 2003).

Supplemental material D. 3D reconstruction of KNM-LT-28752, holotype of Turkanatragus 5 marymuunguae gen. et sp. nov. 